\title{
Multistate Efforts to Answer Consumer Horticulture Questions in eXtension
}

\author{
Richard E. Durham ${ }^{1,3}$ and Candace Harker ${ }^{2}$
}

AdDitional index words. Extension Master Gardeners, Ask an Expert, volunteers

Summary. The Consumer Horticulture Community of Practice (CHCoP), responsible for the Gardens, Lawns, and Landscapes section of eXtension, has historically answered over 35\% of the questions submitted to "Ask an Expert" (AaE)-the eXtension online, e-mail based question and answer system. Extension Master Gardener (EMG) volunteers were initially recruited to help answer questions and were responsible for resolving over $50 \%$ of the horticulture-tagged questions in 2008. With the number of questions related to horticulture nearly doubling on an annual basis, there was concern that EMGs alone would not be able to respond to all the questions. However, as eXtension has become more institutionalized in the land-grant system, county- and state-level extension staff have been encouraged to be involved in AaE. While EMG volunteers continue to play a vital role in answering questions, state extension specialists, and more so, county extension staff, are answering questions as well. This balanced approach seems more sustainable and at least $75 \%$ of questions are now being answered by an expert in the same state where the question originated.

$\mathrm{E}$ fforts to build an eXtension community of practice $(\mathrm{CoP})$ for consumer horticulture began in 2005 as part of a funding initiative by eXtension to establish pioneer communities of practice (Durham, 2008; Meisenbach, 2006). The community's official launch of its website, eXtension Gardens, Lawns, and Landscapes occurred in Feb. 2008 as part of the eXtension integrated national launch (Meisenbach, 2008); however, certain aspects of the site, including the $\mathrm{AaE}$ application, were already being used by the public. The eXtension AaE application has proven to be very popular, with over 73,000 questions being resolved by experts from inception to the end of 2011 (eXtension, 2011a). Over 35\% of these resolved questions $(\approx 26,000)$ were in the category horticulture and primarily answered by members of the $\mathrm{CHCoP}$.

When the $\mathrm{CHCoP}$ was being formed, the intent was to use EMGs as experts for answering AaE questions in eXtension. The EMGs are well suited to this task since they are

\footnotetext{
Department of Horticulture, University of Kentucky, Lexington, KY 40546-0091

This paper was part of the workshop "The Growing Involvement of Horticulture in eXtension: Updates and Opportunities" held 27 Sept. 2011 at the ASHS Conference, Waikoloa, HI, and sponsored by the eXtension (EEXT) Working Group.

${ }^{1}$ Extension Professor

${ }^{2}$ County Extension Agent for Horticulture, retired.

${ }^{3}$ Corresponding author. E-mail: rdurham@uky.edu.
}

trained volunteers and many already work with their local county extension office to answer horticulture questions from the public. However, EMGs are not well organized nationally. Some states have state-wide EMG associations or networks but many do not. Organizing EMGs as AaE responders was impeded by several factors but primarily because of reluctance of state EMG coordinators to commit volunteer time to national $\mathrm{AaE}$ efforts and hesitation by EMGs to answer questions outside their geographic or subject-area comfort zone. A summary of results in 2008 indicated that there were seven states with EMG volunteers who collectively answered $\approx 50 \%$ of the horticulture questions in eXtension (Durham and Harker, unpublished data). Durham (2009) again summarized data for eXtension $\mathrm{AaE}$ and reported that incoming horticulture questions to eXtension had increased exponentially over a 4-year period, and wondered whether this growth could be sustained by the current activities of the CoP. Around this time, the eXtension leadership, along with many state extension directors, began to stress institutionalization or the integration of eXtension tools and involvement of state extension staff in eXtension efforts (Ritchie-Holbrook, 2009). Integrating county extension staff in eXtension would have a demonstrative impact on the effectiveness of
eXtension tools such as AaE. This paper addresses trends in eXtension AaE activity for the category "horticulture" and investigates whether institutionalization has played a role in who answers AaE questions.

\section{Methods and materials}

Information regarding questions answered through eXtension $\mathrm{AaE}$ was obtained at the eXtension AaE site (eXtension, 201 lb) filtered by source: all sources; category: horticulture; and location: all locations. With a data set that included almost 20,000 resolved questions, question analysis was limited to 12 dates encompassing four years (Table 1). For these dates, each question was categorized by who answered the question (EMGs, county extension staff, or state extension specialist) and whether the state of origin of the question and location of the expert who answered the question was the same. Questions of anonymous origin and those originating from locations outside the United States were excluded from the analysis. This resulted in the categorization of a total of over 1400 questions.

\section{Results and discussion}

For the first four sets of data representing questions generated from Sept. 2007 through Sept. 2008, EMG volunteers answered more than half of the questions identified (Table 1). During this time, the AaE system was being used primarily by Minnesota Master Gardeners who were betatesting the system with a redirect to the eXtension AaE from the existing Ask a Minnesota Master Gardener (Meyer and Jarvis, 2003). This explains why the majority of questions were answered by EMGs. Many of the county extension staff and state extension specialists answering questions during this time were from Kentucky because a previous question and answer system, Gardendata. org (Durham, 2007), was redirected to eXtension AaE. The experts from Gardendata who transferred to eXtension were a mix of county and state extension staff and specialists. Durham (2009) summarized this data and lamented that with the exponential increase in use of $\mathrm{AaE}$ by home gardeners, the system might soon overwhelm the commitment of experts who were answering questions. 
Table 1. Question date, responder category, location of response, and number of questions analyses for Ask an Expert incoming questions to the eXtension Consumer Horticulture community of practice.

\begin{tabular}{|c|c|c|c|c|c|c|}
\hline \multirow[b]{2}{*}{$\begin{array}{l}\text { Date of incoming } \\
\text { question }\end{array}$} & \multirow[b]{2}{*}{$\begin{array}{c}\text { Questions } \\
\text { (no.) }\end{array}$} & \multicolumn{3}{|c|}{$\begin{array}{l}\text { Questions answered by responder category } \\
[\text { no. (\% for date })]\end{array}$} & \multirow[b]{2}{*}{$\begin{array}{l}\text { Questions } \\
\text { answered } \\
\text { locally }(\%)^{\mathrm{z}}\end{array}$} & \multirow[b]{2}{*}{$\begin{array}{c}\text { States with } \\
\text { experts } \\
\text { responding (no. }\end{array}$} \\
\hline & & $\begin{array}{c}\text { Extension } \\
\text { Master } \\
\text { Gardener }\end{array}$ & $\begin{array}{c}\text { County } \\
\text { extension } \\
\text { staff }\end{array}$ & $\begin{array}{c}\text { State } \\
\text { extension } \\
\text { specialist }\end{array}$ & & \\
\hline 20-27 Sept. 2007 & 22 & $20(91)$ & $2(9)$ & 0 & 86 & 3 \\
\hline 1-8 Apr. 2008 & 62 & $39(63)$ & $12(19)$ & $11(18)$ & 61 & 12 \\
\hline 23-31 Мау 2008 & 50 & $36(72)$ & $3(6)$ & $11(22)$ & 47 & 11 \\
\hline 20-27 Sept. 2008 & 54 & $30(56)$ & $11(20)$ & $13(24)$ & 76 & 13 \\
\hline 1-8 Apr. 2009 & 76 & $23(30)$ & $37(49)$ & $16(21)$ & 58 & 12 \\
\hline 23-31 May 2009 & 118 & $67(57)$ & $39(33)$ & $12(10)$ & 53 & 10 \\
\hline 20-27 Sept. 2009 & 128 & $39(30)$ & $48(38)$ & $41(32)$ & 72 & 13 \\
\hline 1-8 Apr. 2010 & 229 & $74(32)$ & $104(45)$ & $51(22)$ & 74 & 26 \\
\hline 23-31 May 2010 & 130 & $67(51)$ & $27(21)$ & $36(28)$ & 59 & 18 \\
\hline 20-27 Sept. 2010 & 196 & $69(35)$ & $49(25)$ & $78(40)$ & 51 & 25 \\
\hline 1-8 Apr. 2011 & 197 & $68(34)$ & $66(34)$ & $63(32)$ & 84 & 25 \\
\hline 23-31 May 2011 & 216 & $79(37)$ & $53(25)$ & $84(38)$ & 76 & 23 \\
\hline
\end{tabular}

${ }^{2} \mathrm{~A}$ locally answered question indicates that the question was answered by an expert in the same state as where the question originated.

In an effort to engage additional EMG state coordinators in eXtension, and thereby recruit more EMGs as experts for $\mathrm{AaE}$, the $\mathrm{CHCoP}$ began to direct resources toward engaging this audience (EMG blog, EMG coordinators online discussions).

In 2009, institutionalization of eXtension was being emphasized by several state extension directors. The data from Table 1 reflect an increase in activity especially among county extension staff, which may indicate that institutionalization of eXtension has been somewhat successful. Also, as use of eXtension expanded to more and more states, the percent of questions being answered by a local expert has increased or stayed the same as well as did the number of states with experts responding.

While the initial goal of having EMG volunteers answer a majority of questions in eXtension $\mathrm{AaE}$ has not been achieved, a network of experts from across the United States has developed who primarily answer questions generated within their own state. All these experts play a vital role in providing research-based information to the gardening public, most are providing the same services that they have always provided to clientele; however, these experts are now using new technologies to meet the public's needs, and so should be equally rewarded by their extension administrators for doing do. Their work helps ensure the long-term sustainability of the eXtension CHCoP and the AaE application of eXtension Gardens, Lawns, and Landscapes website.

\section{Literature cited}

Durham, R.E. 2007. GardenData.org, an interactive, online database of home and garden FAQ for Kentucky. HortScience 42:966. (abstr.).

Durham, R.E. 2008. The role of consumer horticulture in eXtension. Hort Science 43:1073. (abstr.).

Durham, R.E. 2009. eXtension Consumer Horticulture Community of Practice blog: 3 Sept. 2009. How do we make the GLL ask an expert system more sustainable? 8 May 2012.<http://consumer hortcop.wordpress.com/2009/09/03/ how-do-we-make-the-gll-ask-an-expertsystem-more-sustainable/>.
eXtension, 2011a. Incoming questions. 29 May 2012. <http://www.extension. org/aae/incoming $>$.

eXtension. 2011b. All reports, select a report. 10 May 2012. <http://www. extension.org/aae/reports $>$.

Meisenbach, T. 2006. About eXtension blog: Sept. 6th 2006. eXtension names ten new communities of practice. 7 May 2012. <http://about.extension.org/ 2006/09/06/extension-names-tennew-communities-of-practice $>$.

Meisenbach, T. 2008. About eXtension blog: Feb. 20th, 2008. eXtension launches 21 Feb. 2006. 7 May 2012. <http://about.extension.org/2008/ $02 / 20 /$ extension-launches-february- 21 $2008 />$.

Meyer, M.H. and B.R. Jarvis. 2003. Electronic “Ask a Master Gardener" answers gardening questions. J Ext. 4l(1). 8 May 2012. <http://www.joe.org/joe/ 2003february/iw3.shtml>.

Ritchie-Holbrook, H. 2009. About eXtension blog: Oct. 27th, 2009. General session recordings from 2009 national eXtension conference. 8 May 2012. <http://about.extension.org/2009/10/ 27 /general-session-recordings-from2009-national-extension-conference/>. 